\title{
Blackboard Collaborated-Based Instruction in an Academic Writing Class: Sociocultural Perspectives of Learning
}

\author{
Hlaviso Motlhaka \\ University of Limpopo, School of Education, South Africa \\ hlavisomhlanga@yahoo.com \\ DOI: 10.34190/EJEL.20.18.4.006
}

\begin{abstract}
Academic writing in higher education involves acculturation of discourse characterised by new and unfamiliar social, cultural and academic conventions which remain a huge challenge for instructors and students worldwide. This study aimed at investigating the use of Blackboard Collaborated-Based Instruction to improve academic writing skills of second language writers. Drawing from Vygotsky's sociocultural framework, this study is premised on online collaborative writing tasks which encourage peer feedback and the exchange of ideas that gives sense of an audience larger than one consisting only of the teacher. Data were collected through metacognitive reflective interview of eight first-year students registered for a Bachelor of Education degree programme. The findings show that Blackboard Collaborated-Based Instruction provided second language writers with an online learning community in which they collaborate and help each other in editing, revising, and improving their academic essay through peer feedback. The findings also provide an insight into how learning academic writing skills is facilitated by scaffolding between peers wherein Blackboard Collaborated-Based Instruction serves as a mediator in students' development of academic writing.
\end{abstract}

Keywords: Blackboard Collaborated-Based Instruction, Vygotsky's sociocultural framework, collaborative writing tasks, academic writing, peer feedback

\section{Introduction}

Higher education institutions (HEls) are increasingly embracing online modes of instruction. An additional complexity in the online teaching environment is the diversity of the online student population resulting in variation in motivation, engagement and learning capabilities. This correlates to the increased use of studentcentred learning approaches to cater for students' prior experiences, learning needs and create extra learning opportunities for them. In higher education, integration of technology in teaching and learning of academic literacy includes supporting flexibility and diversity, enhancing the learning experience, engaging students outside the classroom as well as increasing efficiency and cost-effectiveness (Sharpe et al, 2006; Garrison and Vaughan, 2008; Wladis, Conway and Hachey, 2016; Roddy et al., 2017; Ryder et al, 2017; Steele, Holbeck and Mandernach, 2019). Therefore, integration of technology in teaching and learning leads to the practice of academic and field-specific language and communication skills to allow flexibility and convenience through the online components while retaining the benefits of classroom interactive face-to-face experience. However, online learning has been criticised for the lack of physical presence which can complicate the cognitive, metacognitive and social learning, particularly in discussion and other oral communication situations (Gregory and Lodge, 2015). The major causes for concern with online environments have been the unsuitability with students who need individual attention or who are not competent with computer use (Moskal, Dziuban and Hartman, 2013; Gregory and Lodge, 2015; Allen and Seaman, 2017). Hence, online learning offers students flexibility, but requires discipline, time management skills and comfort with technology (Napier, Dekhane and Smith, 2011).

Due to the emerging integration of technology in teaching and learning, many higher education institutions around the world have adopted Blackboard-based instruction because of its easiness, and accessibility. It encourages students to get involved in online learning environment such as virtual classrooms, discussion forums, writing assignments, and getting feedback from teachers and peers (Mohsen and Shafeeq, 2014; Hunt, 2015). Thus, Blackboard-based instruction underpins learner-centered and constructivist learning principles because it ensures equal participation among students, unlike face-to-face discussions which tend to be relatively unbalanced because one or two students may dominate class discussions. Several scholars found that Blackboard-based instruction allows students to access learning materials at their own pace and provides auditory, visual, and kinesthetic cues for a wide range of learning styles (Barber, King and Buchanan, 2015; Alharbi, 2015; Beth et al, 2015; Bolsen, Evans and Fleming, 2016; Hussein, 2016; Alzahrani and Aljraiwi, 2017).

Over the last few years, academic writing teaching in higher education has been changing as a result of advances in science and technology. Academic writing in higher education has expanded to include various levels of ISSN 1479-4403

(CACPIL Reference this paper: Motlhaka, H., 2020. Blackboard Collaborated-Based Instruction in an Academic Writing Class: Sociocultural Perspectives of Learning. The Electronic Journal of e-Learning, 18(4), pp. 337-346, available online at www.ejel.org 
blending as language learning can be seen to benefit from a thoughtful integration of both classroom learning and online learning (Baxter and Haycock, 2014; Cope and Kalantzis, 2015; Duff and May, 2017; Duff and Doherty, 2019). Thus, technology could improve second language writers' ability to communicate with their readers, having a sense of audience and writing to the expectations of that audience, using peer review effectively. These elements are particularly poignant when teaching academic writing for non-native speakers of English at university level in countries such as South Africa, where English for specific purposes and English for academic purpose courses are a required part of the university Bachelor's degree in most degree programmes.

The use of technology affords online collaborative writing tasks and interactive practices which encourage peer feedback and the exchange of ideas (Limbu and Markauskaite, 2015; Heinerichs, Pazzaglia and Gilboy, 2016), increases engagement, and facilitates instructional feedback (Bikowski and Vithanage, 2016; Vicentini and de Oliveira, 2018). Blackboard Collaborated-Based Instruction provides students with the opportunity of social interaction and participation to build knowledge infrastructure in a manner that allows for continuous learning based on technology and modern means of communication (Alzahrani and Aljraiwi, 2017). Blackboard's Self and Peer Assessment tools through Blackboard Collaborated-Based Instruction are designed to enhance reflective learning skills such as reviewing the work of peers through criterion-based reference evaluation which promotes constructive feedback. The constructive feedback that students receive from their peers can provide valuable insights into their own efforts because it maintains the fairness of assessment hence every student has the opportunity to assess each other and to learn from each other's work. In the context of this study, the university has supported the growing initiative to integrate interactive computer-mediated learning environment in language instruction and to investigate its effect on developing English language skills and proficiency. In this regard, developing writing proficiency represents a real challenge to English majors who struggle to produce quality writing. There is a general consensus that writing proficiency is multi-componential in nature and its main core can be captured in three dimensions: accuracy, fluency, and complexity (Kassem, 2018) as indicators of students' oral and written proficiency which date back to the 1980s when second language research made a distinction between fluency and accuracy in second language usage. Brumfit (1984) is one of the pioneers who used the accuracy-fluency dichotomy to distinguish two kinds of activity: accuracy-oriented activities and fluency-oriented activities. Complexity as the third dimension, was later added by Skehan (1998) who created a model in which accuracy, fluency and complexity became the three basic proficiency indicators.

Many researchers believe that second language proficiency consists of multi-componential constructs and that their principal dimensions can be captured by complexity, accuracy and fluency (CAF) model (Skehan, 1998). Thus, CAF emerged as distinct components of second language performance and second language proficiency which can be separately measured and variably manifested under varying conditions of second language use which may be differentially developed by different types of students under different learning conditions. CAF becomes principal epiphenomena of the psycholinguistic mechanism and processes underlying the acquisition, representation and processing of second language (Hokamura, 2018). In other words, complexity and accuracy together reflect the current level of language knowledge, whereas fluency represents students' control over their linguistic second language knowledge. It is worth-noting that there are many definitions for the components of CAF. In this study, complexity is defined as progressively more elaborate language and a greater variety of syntactic patterning (Foster and Skehan, 1996) and accuracy is defined as the ability to be free from errors while using language to communicate, while fluency is defined as the number of words or structural units a writers are able to include in their writing within a particular period of time (Wolfe-Quintero, Inagaki and Kim, 1998). In this study, the development of English writing is viewed as a system and the elements of CAF are viewed as subsystems that influence language development through writing. This study attempts to provide a holistic and practical understanding of students' experience using Blackboard Collaborated-Based Instruction as a support tool to improve their academic writing skills through analyzing and critiquing each other's work. Broadly, the purpose of this study is to examine students' experience of using Blackboard Collaborated-Based Instruction. Overall, the findings could enable a greater understanding of how students use this type of resource and its perceived value for student learning.

\section{Theoretical framework}

Through sociocultural theory, learning becomes a social process whose key tenets are human interaction and culturally mediated activity (Vygotsky, 1978). Writing practices established through a collaborative writing enable mediated learning and the negotiation of meaning (Lantolf, 2000), and the use of technology can afford collaborative and interactive practices in various instructional environments. The collaborative process involved 
in writing makes it not only a means of communication, but also a form of social action (Fletcher and Bullock, 2015; Fathi and Khodabakhsh, 2019). Grounded in sociocultural theory, peer feedback provides students with scaffolding opportunities to advance their zones of proximal development (Indarti, 2018; Karim and Nassaji, 2019; Ismiati and Pebriantika, 2020) in collaboration with more capable peers. Peer feedback provides opportunities for students to reflect on their roles as writers and audience, on the negotiation of meaning needed for the intended message to be communicated successfully, and on the linguistic and rhetorical features necessary to achieve the communication of meaning (Lu and Law, 2012; Myhill, Jones and Wilson, 2016; Loretto, DeMartino and Godley, 2016). This suggests that peer feedback through peer scaffolding lead to coconstruction of knowledge and improvement of students' academic writing performance.

Online collaborative writing tasks encourage peer feedback and the exchange of ideas (Limbu and Markauskaite, 2015; Li, 2018; Li and Kim, 2016), increase engagement and facilitate instructional feedback (Bikowski and Vithanage, 2016). In other words, students who engage in collaboration during peer feedback sessions have the opportunity to negotiate meaning and construct their understanding of language mechanics (local aspect) and discursive features (global aspect). This means that sociocultural theory improves writers' ability to communicate with their readers, having a sense of audience and writing to the expectations of that audience, using peer review effectively, and revising and editing as needed. In other words, learning and knowledge construction is mediated through interaction with others which is situated in authentic environments and tasks where the individual has the opportunity to interact with others and thus becomes self-regulated, self-mediated and self-aware through feedback received from the environment (e.g. others, artifacts) and self-reflection on second language writers' understanding and experience (Yu and Hu, 2017; Huisman et al, 2018; Zhao, 2018; Fathi and Khodabakhsh, 2019). Thus, peer feedback component into second language writing instruction seems not only feasible but also a potential source of construction of knowledge underpinned by Vygotskian theoretical framework of social constructivism/sociocultural theory.

\section{Problem of the study}

Several studies on academic writing found that there are challenges of writing proficiency among students whose linguistic and cultural background from an African perspective due to social and cognitive challenges related to the nature of the second language acquisition (Doyle, 2015; Zhao, 2018; Nasser, 2019; Ismiati and Pebriantika, 2020). These studies show that second language writing conventions are modelled in first language writing despite the fact that second language writing is strategically, rhetorically and linguistically different in many ways from first language writing, particularly to students whose first language is one of South Africa's official indigenous languages such as Xitsonga, Sepedi, Setswana, isiZulu, isiXhosa, isiNdebele, Siswati and Tshivenda. In this case, university environment serves as the most convenient English context for students to write, speak and read in English because English input is insufficient outside the classroom due to the fact that majority of their parents have insufficient English proficiency or are either illiterate or semiliterate. Students' academic writing deficiency could also be attributed to high school teachers' inadequate writing proficiency which denied students expanded opportunities to practice writing. For instance, several scholars found that second language writing teachers prefer written corrective feedback which focuses on grammatical accuracy in terms of when to mark, how to mark, and what to mark on the aspect of pedagogy for second language writing for error correction which may not have any positive effect on second language writing (Semke, 1984; Dukes and Albanesi, 2013; Duff and May, 2017; Canagarajah, 2018; Duff and Doherty, 2019; Karim and Nassaji, 2019). This practice promotes pseudo-learning and teacher-centred that result in pseudo-knowledge for conscious acquisition of explicit grammatical knowledge because it is relatively unbalanced because one or two students may dominate class discussions which denies other students the opportunity to become self-regulated, selfmediated and self-aware through feedback received from the teacher (Hyland and Hyland, 2006; Leki, 2007). The current teaching practices do not provide students with enough opportunity to practice writing or sufficient feedback to improve the quality of their academic essays which could be the main reason for poor writing performance. Many interventions in academic writing focused on identifying principles and practices for designing efficient programmes to address academic writing challenges among second language writers, hence only a few studies have investigated the effect of Blackboard Learning Management System to develop writing skills of students. This study therefore seeks to investigate how Sepedi language students from diverse cultural and linguistic backgrounds use their discursive resources to perform academic writing tasks through Blackboard Learning Management System to improve their academic writing skills drawing from Vygotsky's sociocultural framework which encourages peer feedback and the exchange of ideas. 


\subsection{Significance of the study}

The results of this study could provide a scientific database for making decisions regarding successful implementation of Blackboard Collaborated-Based Instruction in developing students' academic writing proficiency.

\subsection{Research questions of the study}

The present study seeks to answer the following two main questions:

- What is the impact of using Blackboard Collaborated-Based Instruction on English First Additional Language writers' academic writing proficiency through peer feedback?

- What are the English First Additional Language writers' attitudes towards the use of Blackboard Collaborated-Based Instruction?

\section{Method}

\subsection{Sampling}

The research setting of this study is comprised of one South African comprehensive rural university located in Thohoyandou, Limpopo province. The sample of this study is comprised of students whose first language is one of South Africa's official African languages such as Xitsonga, Sepedi, Setswana, isiZulu, isiXhosa, isiNdebele, Siswati and Tshivenda. The sample included eight first-year students between the ages of 18 to 25 registered in the Academic Literacy module in the School of Human and Social Science at rural university in South Africa. Purposive and convenient sampling were used due to the qualities respondents possess in terms of diverse cultural and linguistic backgrounds drawn from their Sepedi first language.

\subsection{Data collection}

The primary data for the study came from participant-generated academic essays and focus group interviews.

\subsubsection{Academic essays}

Respondents wrote descriptive essays in English on different individual topics of their choice approved by the instructor to avoid duplication and copying each other's essay. The topics were considered to be at a similar level of difficulty. In the first two weeks of the course, students were informed about the course structure concerning academic essay assignment and peer feedback process through Blackboard Collaborated-Based Instruction. It was therefore mandatory for students to submit a draft essay, provide peer feedback and to submit a final draft of the essays within the pre-set deadlines. Respondents were given three days to write their essays and upload them for peer review on Blackboard. The rationale behind the writing and uploading of essays on Blackboard was to assess how second language writers position themselves in texts and what linguistic and rhetorical resources they used through word choices and sentence constructions, as well as how peer feedback shape their understanding and improve their writing skills. Reflection of students on peer feedback would provide them with opportunities to review their work and the work of fellow students and help them to develop their own academic writing style and critical thinking skills. Each student receives anonymous feedback which helps them to develop their writing, whilst encouraging them to look critically at the quality of their own reviews.

\subsubsection{Focus group interview}

The second data collection technique used in this study was focus group interview to explore the experiences of respondents in giving and receiving peer feedback and incorporating it in their second draft as a way of improving their writing skills. During the focus group interview, respondents and the researcher reflected on the academic structure of their essays, with specific focus on the writing of an introductory paragraph, paragraph writing focusing on topic sentence, supporting and concluding sentences as well as concluding paragraph. Drawing from Vygotsky's sociocultural framework, this study draws from multiple voices and a socially oriented research procedure which put control of the interaction and construction of knowledge in the hands of respondents rather than the researcher. Thus, respondents compared their first drafts prior to peer feedback with their final drafts to ascertain if peer feedback on the final drafts through Blackboard Collaborated-Based Instruction has changed their writing behaviour and improved their academic writing proficiency. Each respondent was given the opportunity to reflect on his/her writing experience and the impact of peer feedback. The interview session lasted for 60 minutes. 


\subsubsection{Data analysis}

Thematic analysis approach was used to analyse data after the transcription of the interview. This data was triangulated with the analysis and comparison of students' first and final draft after incorporating the peer feedback. The analysis focused on placement of thesis statement in the introduction and conclusion, paragraph structure with topic sentence, logical supporting sentences and logical connectors in second language writing.

\section{Discussion of the findings}

The purpose of this study was to investigate the use and experience of second language writers regarding Blackboard Collaborate-Based Instruction in improving their academic writing performance. The following themes emerged during the analysis of essays and focus group interview: placement of the thesis statement in the introductory paragraph, paragraph structure, logical connectors and conclusion paragraph. Each of the themes is presented and discussed below.

\subsection{Placement of the thesis statement}

The researcher sought to determine whether respondents developed their essays deductively or inductively when placing their thesis statement, or main idea in their essays. According to Yan and Cahill (2008), the thesis statement provides the stance, the belief, or the point of view of the writer; or it states the purpose of the essay and conveys the central or main idea of the text. In this study, it was found that the placement of the thesis statement follows the approach introduced by Kubota (1998) which has four kinds of placing the claim. These four types are deductive, inductive, both, and off. The first type, deductive, characterizes a paper in which a clear point of view is stated right in the beginning of paper followed by specific reasons and evidence supporting the position. In inductive kind, a writer's claim is presented at the end of the paper, and supporting evidence is stated in the beginning. The third type is called both which presents and discusses both points of view on a controversial topic in the beginning of the paper, and the writer's position is delayed until the end. The analysis of six essays showed that thesis statements were placed in the initial position, thereby making the writing style deductive, which indicates a UK and US writing convention, whereas the remaining two thesis statements were inductive as they were presented at the end of the essay with supporting evidence. This analysis suggests that there are different rhetorical orientations and stances that second language writers employ when writing in English. Respondents highlighted the following responses on the placement of the thesis statement prior and after receiving peer feedback:

\section{Excerpt 1}

I did not know how to write it but after receiving peer feedback from my classmates and reading through their essays and subsequently giving them feedback, I confidently think thesis statement should be in the introductory paragraph because it states the purpose of the essay at the beginning which is very important for the reader.

\section{Excerpt 7}

I placed the thesis statement at the end of the introductory paragraph as a way of informing the reader about what the essay is focusing on in relation to issues that are going to be discussed in the essay. After reading my classmates' essays, I realized that a thesis statement could be placed at the beginning of the introductory paragraph even in the conclusion paragraph.

Above excerpts show that respondents know the importance of having a thesis statement in the introduction and conclusion paragraph to specify the position taken by the writer regarding the main ideas discussed in the essay. Respondents preferred placing the thesis statement at the beginning and end which concurs with Liu's (2007) assertion that the placement of the thesis statement has been typically categorized into two types, deductive and inductive, i.e. putting the thesis statement at the beginning and the end. Respondents' preference to place the thesis statement at the beginning concurs with Oshima and Hogue's (1999) argument that the thesis statement should appear at the beginning of a paper, either in the first sentence or in the last sentence of the introductory paragraph to give the readers information about why the topic is interesting as soon as they start to read the essay. This will help readers to focus on the main idea or the central points, and it must be supported by the body of the essay (Indarti, 2018). The results of this study suggest that other respondents opted to lead their readers straight to the main point which gives the reader brief information about the topic as soon as he/she starts to read the essay, helps him/her to focus on the main idea or central points. A thesis statement in the introductory paragraph serves as "attention-grabber" to get the readers' 
attention, so that if they are interested in the topic of the article they will continue to read it or they will stop. However, other respondents preferred to place the thesis statement at the end of the introductory paragraph and conclusion paragraph and restate the main points discussed in the body. In this instance, second language writers were able to formulate specific and concrete thesis statement which determines the clear and simple linear orientation of writing in English through the use of Ubuntu mediated strategy, which advocates knowledge as experimentally and socially based wherein students reflected and shared their writing experiences (Zhao, 2018; Li, 2018).

\subsection{Paragraph structure}

In order to achieve the objective of establishing the effect of using Blackboard on English First Additional language writers' academic writing proficiency, the researcher examined the paragraph structure of the essay focusing on topic sentence, supporting sentences, concluding sentence and logical connectors on the final draft. Respondents said the following in their own words to justify the importance of having a good paragraph structure as they reflected on their final draft after receiving peer feedback and reading through their classmates' essays:

\section{Excerpt 5}

After revising my essay based on peer feedback and reading through my classmates' writing, I realized the importance of having topic sentence, supporting sentence and concluding sentence in a wellstructured paragraph although paragraphs of my essay have topic sentences and supporting sentences only since concluding sentence is optional hence most of my classmates don't have it while it is easy to understand the flow of ideas in their essays.

\section{Excerpt 6}

My revised essay has chronological paragraphs because I made sure that they have topic, supporting and concluding sentences in order to have a logical flow of ideas as compared to my first draft which was not properly written given my limited knowledge on how to write an academic essay.

The above excerpts show that respondents did not know the importance of having a topic sentence, supporting sentence and concluding sentence in a well-structured paragraph to ensure logical flow of ideas prior to peer feedback and reading their classmates' academic essays through Blackboard Collaborated-Based Instruction as indicated by respondent 5 and 6 . This analysis shows that peer feedback through Blackboard Collaborated-Based Instruction helped respondents to write well-structured paragraphs in their final academic essays as compared to their first drafts which were not properly written given their limited knowledge on how to write wellstructured paragraphs of academic essay. The findings of this study deduce that peer feedback through Blackboard Collaborated-Based Instruction helped respondents to see how each sentence flows from the previous one and how each is connected to the topic sentence in their paragraphs throughout their academic essays. In other words, information and ideas should be arranged into paragraphs to make the writing more logical and to ensure that the argument flows and develops logically by linking each other logically and linguistically in the whole academic essay. This study affirmed that peer feedback through Blackboard Collaborated-Based Instruction assisted second language writers to gain confidence on their ability to write wellstructured paragraphs in academic essays and to harmonize their completion of meaning expressed in the texts (Myhill, Jones and Wilson, 2016).

\subsection{Logical connectors}

Logical connectors are used to join or connect two ideas that have a particular relationship which could be sequential (time), reason and purpose, adversative (opposition and/or unexpected result), condition in academic writing. They include coordinating conjunctions such as and, but, or, nor, so; adverbial subordinators such as because, since, although and conjunctive adverbials such as first, also, however, and additionally to develop logic and cohesiveness in an academic essay (Aryadoust and Liu, 2015; Yin, 2015; Ha, 2016; Jiangang, 2017). Respondents said the following in their own words to justify the importance of having logical connectors as a way of ensuring logical sequence of ideas as they reflected on their final draft: 


\section{Excerpt 4}

Peer feedback helped me to understand the use logical connectors when writing an academic essay because I had no idea as to how to use them prior receiving feedback on my first draft and reading through my classmates' essays.

\section{Excerpt 8}

I was not aware of the significance of words like however, in conclusion, and on the contrary among others until I read through my classmates' essay and getting a comprehensive peer feedback which clearly stated the appropriate usage to coherently and cohesively connect different ideas in the paragraph.

Above excerpts show that respondents did not know the significance of logical connectors until they read their classmates' essays and getting comprehensive peer feedback through Blackboard Collaborated-Based Instruction from their classmates which clearly stated the appropriate use of logical connectors to connect different ideas coherently and cohesively in their essays. Therefore, the findings of this study deduce that peer feedback through Blackboard Collaborated-Based Instruction helped respondents to learn from each other about the importance and appropriate use of logical connectors in academic essay writing to ensure logical flow of ideas. The findings of this study correlate with the findings of Fathi and Khodabakhsh (2019) who found that peer feedback enhances learning and helps students to gain a clear understanding of the assessment criteria which can also foster their own learning. It could therefore be suggested that peer feedback provides students with the opportunities to think about their own learning process, activate and employ their previous knowledge, make inductions, incorporate ideas, compensate for inadequate understandings and clarify their understandings.

\subsection{Students' perceptions of the value of peer feedback towards the use of Blackboard Collaborated-Based Instruction}

The success of a writing instruction approach which incorporates peer feedback depends on students' perceptions. Respondents said the following in their own words to justify their perceptions on peer feedback in academic writing:

\section{Excerpt 2}

At least for me it was useful to get peer feedback from other students on my writing and it was also good to read others' essays.

\section{Excerpt 3}

I liked this forum because I could help my classmates by giving them suggestions for improvement by critically reviewing their essays. I also like comments that are useful for me to improve my essay.

\section{Excerpt 9}

Commenting and responding to others through an online discussion board helps me develop my thoughts and ideas.

Above excerpts show that respondents acknowledge that Blackboard Collaborated-Based Instruction provides them with the opportunity and platform to extend their interactions with peers wherein they help each other to improve their academic writing by giving each other suggestions for improvement by identifying their strengths and weaknesses in their writing. The findings of this study deduce that peer feedback through Blackboard Collaborated-Based Instruction enhances respondents' sense of audience as they view their peers as the real audience for their writing; raises their awareness through their giving and receiving of feedback, which contributed to helping them to transfer their ability to correct others' mistakes and develop metacognitive abilities to correct their own as a way of improving each other's writing. The findings of this study concur with the findings of other researchers who found that peer feedback through Blackboard Collaborated-Based Instruction helps second language writers to increase their metacognitive understanding of writing and to produce higher-quality of their writing (Lu and Law, 2012; Zheng, Yim and Warschauer, 2017). In other words, the results of this study suggest that peer feedback is a viable option for improving second language writing that can be incorporated into learner-centered writing instruction which has the potential to help students develop 
their writing ability by providing them with the opportunity to extend their interactions with peers and teachers, expand their social repertoire, and make their voices heard wherein they participate in a safer and more liberating environment and control their learning process at their own pace. Furthermore, the findings of this study reveal that peer feedback through Blackboard Collaborated-Based Instruction helps students to take ownership of their work and develop greater audience awareness as they engage in timely conversations with authentic readers about how to revise their academic essays. These findings correlate with the findings of other researchers who found that peer feedback leads to improvements in students' writing and increased understanding of the expectations and genres of academic writing; thus, it is often hailed as a "best practice" in writing instruction (Huisman et al,, 2018; Loretto, DeMartino and Godley, 2016).

\section{Conclusion}

The study investigated the experience of second language writers regarding the use of Blackboard CollaboratedBased Instruction in improving their academic writing performance. The study found that Blackboard Collaborated-Based Instruction through sociocultural theory encourages peer feedback and the exchange of ideas, increase engagement, and facilitates instructional feedback to improve second language writers' academic writing skills (Bikowski and Vithanage, 2016). The results provide an insight into how learning academic writing skills is facilitated by the peer scaffolding between peers which focuses from what to do and how to do it. Through sociocultural theory, peer scaffolding views knowledge as open process in which second writers share knowledge, evaluate evidence and consider options in a reasonable and equitable manner through peer feedback. This means that scaffolding raises students' awareness of the conventions within which they are expected to write and helping them to add these conventions to their linguistic and rhetorical repertoires in academic writing; and nurtures their confidence as writers. Thus, fostering critical reflection in second language writers helps to enhance their process of learning to write, especially in collaborative online settings which provided repositories that they utilized to scaffold their academic writing needs. This suggests that second language writers became more confident, and felt that they made progress in their academic writing by identifying writing errors and adapting academic writing conventions due to an encouraging environment that prevailed among them as peers. In this case, Blackboard Collaborated-Based Instruction provided an online learning community in which second language writers collaborated and helped each other by editing and revising to improve their English academic writing. These findings support the theory of the Zone of Proximal Development in which Vygotsky posits that students can learn better with the assistance of more capable peers (students), adults (teachers and experts), and artifacts (Blackboard Collaborated-Based Instruction). However, it should be noted that Blackboard Collaborated-Based Instruction does not replace face-to-face communications among students and teachers in higher education learning communities, but the best practice could be a combination of face-to-face and computer-mediated communication.

One implication that second language writing teachers can draw from the study is that technology can be effective in improving English First Additional Language students' academic literacy skills in providing second language writers with socio-linguistic interaction and psychological/emotional support to enhance their cognitive/linguistic writing abilities. In other words, the existence of online community provides an authentic audience among students to read for one another critically and supportively and positive feedback which is conducive to reinforcing and consolidating academic literacy development, including academic writing processes because it gives second language writers time to identify what the writer wants to convey and to provide meaningful and constructive feedback. Future research that is expected to emerge from the present study could examine computer-mediated peer responses in reading, listening, and speaking class as well as in content subject classes (e.g., Economics, History, Business Studies, Biology, among others) to facilitate the process of students' acquisition of academic literacy.

\section{References}

Alharbi, M., 2015. Effects of Blackboard's discussion boards, blogs and wikis on effective integration and development of literacy skills in EFL students. English Language Teaching, 8(6), pp.111-132.

Allen, E. and Seaman, J., 2017. Digital learning compass: distance education enrolment report 2017. Babson Survey Research Group, e-Literate, and WCET.

Alzahrani, M.M and Aljraiwi, S.S., 2017. Effectiveness of using Blackboard collaborate tools in promoting practical skills among students of the foundation year in e-learning course. British Journal of Education, 5(4),pp.19-53.

Aryadoust, V. and Liu, S., 2015. Predicting EFL writing ability from levels of mental representation measured by Coh-Metrix: A structural equation modeling study. Assessing Writing, 24, pp.35-58. 
Barber, W., King, S. and Buchanan, S., 2015. Problem based learning and authentic assessment in digital pedagogy: embracing the role of collaborative communities. The Electronic Journal of E-Learning, 13(2), pp.59-64.

Baxter, J. A. and Haycock, J., 2014. International review of research in open and distance learning. The International Review of Research in Open and Distributed Learning, 15(1), pp.7-22.

Beth, A. D., Jordan, M. E., Schallert, D. L., Reed, J. H. and Kim, M., 2015.Responsibility and generativity in online learning communities. Interactive Learning Environments, 23(4), pp.471-484. https://doi.org/10.1080/10494820.2013.788035

Bikowski, D. and Vithanage, R., 2016. Effects of web-based collaborative writing on individual L2 writing development. Language Learning \& Technology, 20(1), pp.79-99.

Bolsen, T., Evans, M. and Fleming, A. M., 2016. A comparison of online and face-to-face approaches to teaching introduction to American Government.Journal of Political Science Education, 12(3), pp.302-317.

Brumfit, C.J., 1984. Communicative methodology in language teaching. Cambridge: Cambridge University Press.

Canagarajah, S., 2018. Translingual practice as spatial repertoires: expanding the paradigm beyond structuralist orientations. Applied Linguistics, 39, pp.31-54.

Cope, B. and Kalantzis, M., 2015. The things you do to know: an introduction to the pedagogy of multiliteracies. In B. Cope and M. Kalantzis (Eds.), A pedagogy of multiliteracies (pp. 1-36). London, UK: Palgrave Macmillan.

Doyle, H., 2015. Multi-competence, ELF, learning and literacy: a reconsideration. International Journal of Social Science and Humanity, 5(10), pp.887-891.

Duff, P. and Doherty, L., 2019. Learning “Chinese" as heritage language: challenges, issues, and ways forward. In: C.-R. Huang, Z. Jing-Schmidt, and B. Meisterernst (Eds.), Routledge handbook of Chinese applied linguistics. New York: Routledge/Taylor \& Francis.

Duff, P. and May, S., (Eds.). 2017. Language socialization. Encyclopedia of language and education (3rd. ed.). Cham, Switzerland: Springer.

Dukes, R.L. and Albanesi, H., 2013. Seeing red: quality of an essay, colour of the grading pen, and student reactions to the grading process. The Social Science Journal, 50(1), pp.96-100.

Fathi, J. and Khodabakhsh, M. R., 2019. The role of self-assessment and peer-assessment in improving writing performance of Iranian EFL students. International Journal of English Language and Translation Studies, 7(3), pp.1-10.

Fletcher, T. and Bullock, S. M., 2015. Reframing pedagogy while teaching about teaching online: a collaborative self-study. Professional Development in Education, 41(4), pp.690-706.

Foster, P. and Skehan, P., 1996. The influence of planning and task type on second language performance. Studies in Second Language Acquisition, 18, pp.299-323.

Garrison, D. R. and Vaughan, N. D., 2008. Blended learning in higher education: framework, principles, and guidelines. San Francisco, CA: Jossey-Bass.

Gregory, M. S.J. and Lodge, J. M., 2015. Academic workload: the silent barrier to the implementation of technologyenhanced learning strategies in higher education. Distance Education, 36, pp. 210-230.

Ha, M. J., 2016. Linking adverbials in first-year Korean university EFL learners' writing: a corpus-informed analysis 1. Computer Assisted Language Learning, 29(6), 1090-1101.

Heinerichs, S., Pazzaglia, G. and Gilboy, M. B., 2016. Using flipped classroom components in blended courses to maximize student learning, 11(1), pp.54-57. https://doi.org/10.4085/110154

Hussein, H.E.M., 2016. The effect of Blackboard collaborate-based instruction on pre-service teachers' achievement in the EFL Teaching Methods course at faculties of education for girls. English Language Teaching, 9(3), pp.49-67.

Hokamura, M., 2018. The dynamics of complexity, accuracy, and fluency: a longitudinal case study of Japanese learners' English writing. JALT Journal, 40(1), pp.23-46.

Huisman, B., Saab, N., van Driel, J. and van den Broek, P., 2018. Peer feedback on academic writing: undergraduate students' peer feedback role, peer feedbackperceptions and essay performance. Assessment and Evaluation in Higher Education, 43(6), pp.955-968.

Hunt, A.M., 2015. Blended online learning in initial teacher education: a professional inquiry into pre-service teachers' inquiry projects. Journal of Open, Flexible and Distance Learning, 19(2), pp.48-60.

Hyland, K. and Hyland, F., 2006. Context and issues in feedback on L2 writing: An introduction. I:n K. Hyland \& F. Hyland (Eds.), Feedback in second language writing (pp.1-20). Cambridge, England: Cambridge University Press.

Indarti, D., 2018. Patterns of rhetorical organization in the Jakarta post opinion articles. Studies in English Language and Education, 5(1), pp.69-84.

Ismiati, I. and Pebriantika, E., 2020. Designing strategies for university students' writing skill. Journal of Languages and Language Teaching, 8(1), pp.8-19.

Jiangang, S., 2017. A corpus-based study of contrastive/concessive linking adverbials in spoken English of Chinese EFL learners. Studies in Literature and Language, 14(2), pp.17-25.

Karim, K. and Nassaji, H., 2019. The effects of written corrective feedback: a critical synthesis of past and present research. Instructed Second Language Acquisition, 3(1), pp.28-52.

Kassem, M.A.M., 2018. The effect of using Blackboard on English majors' writing proficiency and attitudes. International Journal of Applied Linguistics and English Literature, 7(6), pp.73-79.

Kubota, R., 1998. An investigation of L1-L2 transfer in writing among Japanese university students: implications for contrastive rhetoric. Journal of Second Language Writing,7, pp.69-100.

Lantolf, J. P., 2000. Introducing sociocultural theory. In: J. P. Lantolf (Ed.), Sociocultural theory and second language learning (pp. 1-26). New York, NY: Oxford University Press. 
Leki, I., 2007. Undergraduates in a second language: challenges and complexities of academic literacy development. New York: Lawrence Erlbaum Associates.

Li, M., 2018. Computer-mediated collaborative writing in L2 contexts: an analysis of empirical research. Computer Assisted Language Learning, pp.1-23.

Li, M. and Kim, D., 2016. One wiki, two groups: dynamic interactions across ESL collaborative writing tasks. Journal Second Language Writing, 31(2016),pp.25-42.

Limbu, L. and Markauskaite, L., 2015. How do learners experience joint writing: university students' conceptions of online collaborative writing tasks and environments. Computers and Education, 82, pp.393-408.

Liu, J.J., 2007. Placement of the thesis statement in English and Chinese argumentative essays: a study of contrastive rhetoric. Electronic Journal of Foreign Language Teaching, 4(1), pp.122-139.

Loretto, A, DeMartino S. and Godley, A., 2016. Secondary students' perceptions of peer review of writing. Research in the Teaching of English, 51(2), pp.134-161.

Lu, J. and Law, N., 2012. Online peer assessment: effects of cognitive and affective feedback. Instructional Science, 40(2012), pp.257-275.

Mohsen, M. A. and Shafeeq, C.P., 2014. EFL teachers' perceptions on Blackboard applications. English Language Teaching, 7(11), pp.108-118.

Moskal, P., Dziuban, C. and Hartman, J., 2013. Blended learning: a dangerous idea? The Internet and Higher Education, 18, pp.15-23.

Myhill, D., Jones, S. and Wilson, A., 2016. Writing conversations: fostering metalinguistic discussion about writing. Research Papers in Education, 31(1), pp.23-44.

Napier, N. P., Dekhane, S. and Smith, S., 2011. Transitioning to blended learning:Understanding student and faculty perceptions. Journal of Asynchronous Learning Networks, 15(1), pp.20-32.

Nasser, S.M., 2019. Iraqi EFL students' difficulties in writing composition: an experimental study (University of Baghdad). International Journal of English Linguistics, 9(1), pp.178-184.

Oshima, A. and Hogue, A., 1999. Writing academic English. London: Longman.

Roddy, C., Amiet, D.L., Chung, J., Holt, C., Shaw, L., McKenzie, S., Garivaldis, F.,Lodge, J.M. and Mundy, M.E., 2017. Applying best practice online learning, teaching and support to intensive online environments: an integrative review. Frontiers in Educatio, 2(59), pp.1-10.

Ryder, G., Russell, P., Burton, M., Quinn, P. and Daly, S. 2017. Embedding peer support as a core learning skill in higher education. Journal of Information Literacy, 11(1), pp.184-203.

Semke, H.D., 1984. Effects of the red pen. Foreign Language Annals, 17(3), pp.195-202.

Sharpe, R., Benfield, G., Roberts, G. and Francis, R., 2006. The undergraduate experience of blended e-learning: a review of UK literature and practice. Oxford: Higher Education Academy

Skehan, P. and Foster, P., 1999. The influence of task structure and processing conditions on narrative retellings. Language Learning, 49, pp.93-120.

Skehan, P.,1998. A cognitive approach to language learning. Oxford: Oxford University Press.

Steele, J., Holbeck, R. and Mandernach, J., 2019. Defining effective online pedagogy. Journal of Instructional Research, 8(2), pp.5-8.

Vicentini, C. and de Oliveira, L.C., 2018. Using technology tools in writing instruction. NYS TESOL Journal, 5(2), pp.44-51.

Vygotsky, L.,1978. Mind in society: The development of higher psychological processes. Cambridge, MA: Harvard University Press.

Wladis, C., Conway, K. M. and Hachey, A. C., 2016. Assessing readiness for online education - research models for identifying students at risk. Online Learn, 20, pp.97-109.

Wolfe-Quintero, K., Inagaki, S. and Kim, H.Y.,1998. Second language development in writing: Measures of fluency, accuracy and complexity. Manoa, HI: Second Language Teaching \& Curriculum Center, University of Hawaii.

Yan, L. and Cahill, D., 2008. The rhetorical organization of Chinese and American students' expository essays: a contrastive rhetoric study. International Journal of English Studies, 8(2), pp.113-132.

Yin, Z., 2015. The use of cohesive devices in news language: overuse, underuse or misuse?. RELC Journal, 46(3), pp.309326.

Yu, S. and Hu, G., 2017. Understanding university students' peer feedback practices in EFL writing: insights from a case study. Assessing Writing, 33(2017), pp.25-35.

Zhao, H., 2018. Exploring tertiary English as a Foreign Language writing tutors' perceptions of the appropriateness of peer assessment for writing. Assessment \& Evaluation in Higher Education, 43(7), pp.1133-1145.

Zhao, H., 2018. New insights into the process of peer review for EFL writing: a process-oriented socio-cultural perspective. Learning and Instruction, 58 (2018), pp.263-273.

Zheng, B., Yim, S. and Warschauer, M., 2017. Social media in the writing classroom and beyond. The TESOL Encyclopedia of English Language Teaching, 1-5. 